\section{Distribution of Ammonia in Larvæ of Lucilia cuprina}

IT has been established that sterile larvæ of Lucilia sericata excrete the bulk of their nitrogen in the form of ammonia ${ }^{1,2}$. Similar studies with larvæ of the Australian sheep blowfly, L. cuprina, support these findings. When reared on a medium composed of yeast, egg white and sodium chloride ${ }^{3}$ the ammonia excretion per 100 larvæ increased after hatching until the larvæ were fully grown and then it diminished rapidly as they approached the pupal state.

This work has been extended to a microchemical study of the distribution of ammonia in the organs and tissues of larvæ of L. cuprina. For qualitative testing, mature larvæ were opened under isotonic saline ( 1.5 per cent sodium chloride). The saline was then removed and the reagent applied. Nessler's reagent and Riegler's reagent were each employed. The latter was prepared according to the directions of Feigl ${ }^{4}$, saturated calcium hydroxide being used to render the solution alkaline.

For the quantitative study, the larvæ were reared on the artificial egg white-yeast medium containing 0.01 per cent brom cresol purple. As shown by Waterhouse ${ }^{5}$, this indicator serves to define the acid mid-segment of the midgut. For each experiment, 10 larvæ were subdivided into the required portions. The dissections were performed under isotonic borax $\left(2.5\right.$ per eent $\left.\mathrm{Na}_{2} \mathrm{~B}_{4} \mathrm{O}_{7}\right)$ to prevent the formation of ammonia during treatment and ammonia was estimated by adapting the permutit-Nessler method ${ }^{6}$ to deal with micro quantities.

As shown in the accompanying table, the results obtained by the three methods agree fairly well.

\begin{tabular}{|c|c|c|c|c|c|c|c|c|}
\hline \multirow{2}{*}{ Method } & \multirow{2}{*}{ 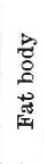 } & \multirow{2}{*}{ 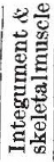 } & \multicolumn{3}{|c|}{ Midgut } & \multicolumn{2}{|c|}{ Hindgut } & \multirow{2}{*}{ 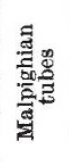 } \\
\hline & & & 总点 & 물 & 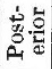 & 妾荌要 & 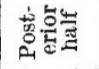 & \\
\hline $\begin{array}{l}\text { Qualitative } \\
\text { Nessler's Reagent } \\
\text { Riegler's Reagent }\end{array}$ & + & + & $\overline{-}$ & $\begin{array}{l}++ \\
++\end{array}$ & - & $\begin{array}{r}++ \\
++\end{array}$ & $\begin{array}{r}+++ \\
++t\end{array}$ & $++\stackrel{+}{+}$ \\
\hline $\begin{array}{l}\text { Quantitative } \\
\text { mgm. per cent } \\
\text { NH }_{3}-\mathrm{N} \\
\text { (Av. of } 9 \text { experi- } \\
\text { ments) }\end{array}$ & 21 & 3 & 11 & 27 & 4 & 206 & 544 & 77 \\
\hline
\end{tabular}

These data help to elucidate the mechanism of ammonia formation and excretion in this organism. They are interpreted as showing that ammonia, produced in the midgut, is absorbed into the hæmocoele and transferred to the Malpighian tubes. The dilute ammonia solution, transmitted from the Malpighian tubes to the hindgut, is gradually concentrated by re-absorption of water as it moves along the hindgut towards the anus. This view of the mechanism of ammonia excretion, which implies that ammonia passes into the body cavity, is also supported by analyses of the hæmolymph, which contains $12 \mathrm{mgm}$. per cent $\mathrm{NH}_{3}-\mathrm{N}$. Acidity in the mid midgut would explain the high ammonia capacity of the gut contents in that region. Ammonia is occasionally detected in the crop if the diet has become rich in excreted ammonia.

Except in the alimentary canal and the Malpighian tubes, the ammonia concentration is relatively low. Some storage of ammonia occurs in a few cells of the fat body, and a portion resides in the integument, sometimes becoming visible as a thin brown line just beneath the cuticle when Nessler's reagent is applied.
A fuller discussion of this work will be published in Australia by the Council for Scientific and Industrial Research. ${ }^{7}$

Division of Economic Entomology,

F. G. LenNox.

Council for Scientific and Industrial Research, Canberra.

May 21.

${ }^{1}$ Michelbacker, A. E., Hoskins, W. M., and Herms, W. B., J. Exp. Zool., 64, 109 (1932).

${ }^{2}$ Brown, A. W. A., Biochem. J., 32, 903 (1938).

${ }^{3}$ Lennox, F. G., Coun. Sei. Ind. Res. (Aust.). Pamphlet No. 93 (1939).

4 Feigl, F., translated by J. W. Mathews, "Qualitative Analysis by Spot Tests" (Amsterdam: Nordemann Pub. Co., 1937).

${ }^{5}$ Waterhouse, D. F., Coun. Sei. Ind. Res. (Aust.), Pamphlet in press. ' Peters, J. P., and Van Slyke, D. D., "Quantitative Clinical Chemistry", Vol. 2. (Baltimore: The Williams and Wilkins Co., 1932.) "Lennox, F. G. A contribution to the series "Studies of the Physio$\log y$ and Toxicology of Blowflies".

\section{Practical Science in Schools}

I FEEL from my own teaching experience that practical work by pupils is essential in order to avoid that common type of 'learning' in which the pupil obtains credit for knowing work, and himself believes he knows it, merely because he is adept at quoting phrases of which he has not properly understood the meaning ${ }^{1}$. Recently the Spens Report has stressed the educational importance of 'activity' (that is, use of the pupil's knowledge and abilities), and of handwork. These imply that knowledge, if it is to last, must be tested and corrected by being put to practical use, and so converted into a habit; and that, in learning, the hand has an important part to play as an organ of sensation.

Would curtailment of practical work necessarily promote the consideration of social and humanistic contacts ? I fear it would unconsciously encourage a dogmatic and authoritarian attitude, by removing that constant reference to observed fact which is the distinguishing mark of science. Since this experimental attitude permeates both the theoretical outlook of science and its technical use, it is an essential part of all its social values too.

If a science teacher asks himself, at each stage in his teaching, what aims he has in view, and applies an experimental outlook to the problem of how to achieve them, he will find that some traditional practical work can be omitted. But at the same time by watching how children react if allowed to do as they please with, for example, lenses, magnets, earthworms, mechanics apparatus (provided this is large enough for the forces to be felt by the organs with which we normally estimate forces-the sensory nerves of the muscles), he will find many suggestions for pupils' practical investigations bearing on everyday life, scientific method, applications of biology, local industry, etc.

With elementary classes one can often reduce expenditure by using robust commercial apparatus instead of fragile laboratory ware, commerical chemicals when pure ones are not needed, and the products of ordinary shops and of Nature whenever possible. This at the same time brings closer the social and humanistic contacts required.

\footnotetext{
"Hazelwood", Ivy Road,

Bolton, Lanes. Aug. 8.

${ }^{1}$ See also Niturk, June 1 , p. 863 , June 29, p. 1023 and July 27 p. 133 .
} 